\title{
Gambaran Health Belief Model pada Penanganan Fraktur
}

\author{
Jesica C. Umboh, ${ }^{1}$ Angelica M. J. Wagiu, ${ }^{2}$ Andriessanto C. Lengkong ${ }^{2}$
}

\author{
${ }^{1}$ Program Studi Pendidikan Dokter Fakultas Kedokteran Universitas Sam Ratulangi Manado, \\ Sulawesi Utara, Indonesia \\ ${ }^{2}$ Bagian Ilmu Bedah Fakultas Kedokteran Universitas Sam Ratulangi-RSUP Prof. Dr. R. D. \\ Kandou Manado, Sulawesi Utara, Indonesia \\ Email: 17011101093@ student.unsrat.ac.id
}

\begin{abstract}
Alternative medicine or traditional medicine is still widely used as a treatment option, especially in dealing with fractures. A person's belief in curing a disease has a healing effect, albeit, it can also cause various complications in case of mishandling. This condition will affect health behavior related to health belief model. This study was aimed to obtain the health belief model in fracture treatment. This was a descriptive and observational study with a survey design. Data were obtained by using questionnaires. Subjects were all WKI GMIM Kalvari Parigi Tujuh as many as 230 females. The results showed that most subjects were $>50$ years old, had high school/vocational school education, and work as housewives. The majority of subjects chose to go to a masseuse as the initial action when they encountered fracture cases and admission to the hospital was in the third position, after the choice to consume over-the-counter drugs. Based on the health belief model, there were four aspects of perception, namely perceptions of seriousness, vulnerability, benefits, and barriers. Some of the subjects considered that: 1) fracture was not a serious disease; 2) fracture was not a threatening disease; 3 ) fracture treatment did not provide many benefits; and 4) there were many barriers in treating fractures. In conclusion, the public perception of fracture cases is good, but there is still room for improvement. Although the community prefers masseurs to get the initial treatment, the hospital remains a destination if the initial action is not successful. Keywords: health belief model, fractures, fracture management, traditional medicine
\end{abstract}

\begin{abstract}
Abstrak: Pengobatan alternatif atau pengobatan tradisional masih banyak dipakai sebagai pilihan pengobatan terutama dalam menangani fraktur. Kepercayaan seseorang dalam kesembuhan sebuah penyakit tidak hanya membawa dampak penyembuhan, tetapi dapat menyebabkan berbagai komplikasi bila terjadi kesalahan penanganan. Kondisi sakit ini akan memengaruhi perilaku kesehatan sehubungan dengan health belief model. Jenis penelitian ialahj deskriptif observasional dengan desain survei. Pengambilan data menggunakan kuesioner. Subjek penelitian ialah seluruh WKI GMIM Kalvari Parigi Tujuh. Hasil penelitian mendapatkan 230 subjek penelitian, mayoritas berusia >50 tahun, memiliki tingkat pendidikan SMA/SMK, dan bekerja sebagai ibu rumah tangga. Mayoritas subjek penelitian memilih untuk pergi ke tukang pijat sebagai tindakan awal ketika menemui kasus fraktur dan rumah sakit menempati posisi ketiga, di bawah pilihan mengonsumsi obat warung. Berdasarkan health belief model, dilakukan pengukuran pada empat aspek persepi yaitu keseriusan, kerentanan, manfaat, serta hambatan. Didapatkan bahwa sebagian subjek menganggap bahwa: 1) fraktur bukan suatu penyakit yang serius; 2) fraktur bukan suatu penyakit yang mengancam; 3) penanganan fraktur tidak memberikan banyak manfaat; dan 4) banyak hambatan yang dihadapi untuk mengobati fraktur. Simpulan penelitian ini ialah persepsi masyarakat mengenai kasus fraktur sudah termasuk baik, tetapi masih terdapat ruang untuk peningkatan. Masyarakat lebih memilih tukang pijat untuk mendapatkan tindakan awal, namun rumah sakit tetap menjadi tujuan bila tindakan awal tidak berhasil.
\end{abstract}

Kata kunci: health belief model, patah tulang, penanganan fraktur, pengobatan tradisional 


\section{PENDAHULUAN}

Di zaman modern ini, pengobatan alternatif atau pengobatan tradisional masih banyak dipakai untuk menjadi pilihan pengobatan, terutama dalam menangani patah tulang. Pengobatan tradisional untuk patah tulang di Indonesia dikenal dengan nama sangkal putung. Menurut hasil penelitian yang dilakukan oleh Sumirat et al, ${ }^{1}$ alasan masyarakat menerima pengobatan tradisional sangkal putung dikarenakan kepercayaan yang kuat pada diri seseorang dan sugesti dari pihak luar, tingkat kesembuhan cepat, biaya pengobatan murah, dan adanya rasa takut terhadap pengobatan medis. Kepercayaan seseorang dalam penanganan sebuah penyakit dapat membawa dampak penyembuhan, namun bila terjadi kesalahan penanganan dapat menyebabkan berbagai komplikasi. Setiap individu dapat memutuskan pengobatan yang akan diambil untuk menangani fraktur. Keputusan ini dipengaruhi oleh kepercayaan individu terhadap kesehatan, yang dijelaskan dalam teori health belief model.

Health belief model merupakan teori perubahan perilaku kesehatan dan model psikologis yang digunakan untuk memrediksi perilaku kesehatan dengan berfokus pada persepsi dan kepercayaan individu terhadap suatu penyakit. ${ }^{2}$ Teori ini meyakini bahwa individu akan mengubah perilaku terkait kesehatan disebabkan beberapa alasan, yaitu persepsi terhadap risiko terkena penyakit (perceived susceptibility), persepsi terhadap keparahan peyakit (perceived seriousness), persepsi manfaat dan hambatan yang dirasakan dalam mengadopsi perilaku tersebut (perceived benefits and perceived barrier), dan isyarat untuk bertindak atau faktor pendorong (cues to action). Health belief model umumnya digunakan untuk memrediksi perilaku kesehatan preventif dan untuk menjelaskan perilaku individu sakit. ${ }^{3}$

Penelitian mengenai health belief model dan perilaku penanganan fraktur di Indonesia ialah antara lain penelitian yang dilakukan oleh Fardani ${ }^{4}$ di Bandung, Jawa Barat, yang mendapatkan bahwa persepsi manfaat, hambatan, dan faktor pendorong merupakan aspek health belief model yang dominan dalam pemilihan tindakan penanganan fraktur. ${ }^{4}$ Selain itu, Sholihah ${ }^{5}$ di Surabaya, Jawa Timur, mendapatkan bahwa persepsi manfaat, persepsi hambatan dan self-efficacy merupakan aspek health belief model yang dominan dalam pemilihan tindakan penanganan fraktur.

Pengobatan yang kurang tepat dapat menyebabkan permasalahan yang cukup besar. Keterlambatan dalam penanganan atau penanganan yang salah dapat menimbulkan komplikasi seperti neglected fracture. Edukasi yang baik bagi masyarakat dapat memengaruhi kemana pasien akan berobat. Kerjasama antara tenaga kesehatan dengan tukang pijat dapat memberikan pelayanan kesehatan yang baik bagi pasien dengan fraktur.

\section{METODE PENELITIAN}

Penelitian ini dilakukan di Gereja GMIM Kalvari Parigi Tujuh, Kelurahan Kombos Timur. Jenis penelitian ini ialah deskriptif kuantitatif observasional dengan desain survei. Populasi penelitian ialah seluruh Wanita Kaum Ibu (WKI) GMIM Kalvari Parigi Tujuh. Jumlah populasi penelitian sebanyak 230 orang. Sampel penelitian ialah WKI GMIM Kalvari Parigi Tujuh, yang memenuhi kriteria inklusi dan eksklusi. Teknik sampling yang digunakan ialah total sampling.

\section{HASIL PENELITIAN}

Penelitian ini dilakukan Gereja GMIM Kalvari Parigi Tujuh, Kelurahan Kombos Timur pada bulan September-November 2020. Data penelitian diperoleh melalui pengisian kuesioner yang melibatkan 230 orang subjek penelitian.

Tabel 1 memperlihatkan bahwa mayoritas subjek penelitian ini berusia $>50$ tahun memiliki tingkat pendidikan SMA/SMK, dan bekerja sebagai ibu rumah tangga.

Tabel 2 memperlihatkan bahwa mayoritas subjek penelitian ini memilih untuk pergi ke tukang pijat sebagai pengobatan pertama fraktur kemudian ke rumah sakit bila tindakan tersebut tidak berhasil. Tempat yang lebih dipilih sebagai tempat pengobatan terbanyak ialah tukang pijat dengan alasan lebih dipercaya. 
Tabel 1. Karakteristik subjek penelitian

\begin{tabular}{lcc}
\hline Variabel & Frekuensi & \% \\
\hline Usia (tahun) & & \\
$20-25$ & 36 & 15,7 \\
$26-30$ & 30 & 13,0 \\
$31-35$ & 24 & 10,4 \\
$36-40$ & 37 & 16,1 \\
$41-45$ & 34 & 14,8 \\
$45-50$ & 25 & 10,9 \\
$>50$ & 44 & 19,1 \\
Pendidikan & & \\
Tidak & 1 & 0,4 \\
Sekolah & & \\
SD & 33 & 14,3 \\
SMP & 42 & 18,3 \\
SMA/SMK & 111 & 48,3 \\
Ahli Madya & 4 & 1,7 \\
Perguruan & 39 & 17,0 \\
Tinggi & & \\
Pekerjaan & & \\
Karyawan & 21 & 9,1 \\
Mahasiswa & 12 & 5,2 \\
Swasta & 18 & 7,8 \\
Pegawai & 7 & 3,0 \\
Negeri & & \\
Wirausaha & 2 & 0,9 \\
Ibu Rumah & 147 & 63,9 \\
Tangga & & \\
Total & 230 & 100,0 \\
\hline & &
\end{tabular}

Tabel 2. Pemilihan tindakan

\begin{tabular}{lcc}
\hline \multicolumn{1}{c}{ Variabel } & Frekuensi & \% \\
\hline Tindakan awal & & \\
Dibiarkan & 10 & 4,3 \\
Konsumsi obat warung & 51 & 22,2 \\
Tukang pijat & 127 & 55,2 \\
Rumah sakit & 42 & 18,3 \\
Tindakan lanjutan & & \\
Dibiarkan & 2 & 0,9 \\
Konsumsi obat warung & 34 & 14,8 \\
Tukang Pijat & 87 & 37,8 \\
Rumah Sakit & 107 & 46,5 \\
Tempat yang & & \\
direkomendasikan & & \\
Rumah Sakit & 88 & 38,3 \\
Tukang Pijat & 136 & 59,1 \\
Dukun & 4 & 1,7 \\
Lainnya & 2 & 0,9 \\
Dasar Pemilihan & & \\
Dipercaya & 155 & 67,4 \\
Tradisi turun-temurun & 43 & 18,7 \\
Lainnya & 32 & 13,9 \\
\hline
\end{tabular}

Tabel 3 memperlihatkan bahwa seluruh persepsi responden memiliki distribusi data yang tidak normal sehingga data deskriptif yang digunakan ialah median dan bukan rerata. Terlihat bahwa median persepsi keseriusan ialah $68,75 \%$, median persepsi kerentanan $75 \%$, median persepsi manfaat $75 \%$, dan median persepsi hambatan $62,5 \%$.

\section{BAHASAN}

Pada penelitian ini mayoritas subyek penelitian berusia $>50$ tahun, memiliki tingkat pendidikan SMA/SMK, dan bekerja sebagai ibu rumah tangga. Berdasarkan karakteristik tersebut, dapat terlihat bahwa mayoritas subjek penelitian ini memiliki tingkat pendidikan yang sudah sesuai dengan standar pendidikan di Indonesia, yaitu memenuhi wajib belajar 12 tahun sesuai dengan program Kementerian Pendidikan dan Kebudayaan Indonesia (Kemendikbud). ${ }^{6}$ Semakin tinggi pendidikan, masyarakat diharapkan semakin paham terhadap tindakan pengobatan yang terbaik untuknya. Berdasarkan pekerjaan, terlihat bahwa mayoritas subjek penelitian ini bekerja sebagai ibu rumah tangga yang lebih banyak menghabiskan waktu untuk mengerjakan berbagai kegiatan rumah tangga, sehingga perhatian terhadap keluarga lebih baik daripada subjek penelitian yang memiliki pekerjaan selain ibu rumah tangga.

Berkaitan dengan health belief model, penelitian ini melakukan pengukuran pada subjek penelitian berdasarkan empat aspek persepsi, yaitu persepsi tentang keseriusan yang dirasakan dari fraktur, persepsi tentang kerentanan atau ancaman dari fraktur, persepsi tentang manfaat memeriksakan fraktur, serta persepsi tentang hambatan dalam mengambil tindakan untuk mengatasi fraktur. $^{7}$ Hasil penelitian ini mendapatkan median persepsi keseriusan $68,75 \%$, median persepsi kerentanan $75 \%$, median persepsi manfaat $75 \%$, dan median persepsi hambatan $62,5 \%$. Berdasarkan data tersebut, terlihat bahwa keempat persepsi tersebut berada pada kuartil 3 (50-75\%) yang berarti masih terdapat sebagian subjek penelitian yang menganggap bahwa: 
Tabel 3. Analisis deskriptif data health belief model (HBM)

\begin{tabular}{lcccc}
\hline Variabel persepsi & Normalitas & Median & Min-Max & Rerata \\
\hline Keseriusan & $<0,001$ & 68,75 & $31,25-100,0$ & 66,14 \\
Kerentanan & $<0,001$ & 75,00 & $31,25-100,0$ & 72,2 \\
Manfaat & $<0,001$ & 75,0 & $43,75-100,0$ & 73,94 \\
Hanbatan & $<0,001$ & 62,5 & $31,25-81,25$ & 63,58 \\
\hline
\end{tabular}

1) fraktur bukanlah suatu penyakit yang serius; 2) fraktur bukanlah suatu penyakit yang mengancam; 3) penanganan fraktur tidak memberikan banyak manfaat; dan(4) banyak hambatan yang dihadapi untuk mengobati fraktur. Kesalahan persepsi ini seharusnya bisa diminimalisir sehingga morbiditas dan mortalitas terkait fraktur dapat diturunkan.

Elemen kunci dari Health Belief Model berfokus pada keyakinan individu tentang kondisi kesehatannya. Model ini mendefinisikan faktor-faktor kunci yang memengaruhi perilaku kesehatan sebagai ancaman yang dirasakan individu terhadap penyakit (perceived susceptibility), keyakinan akan konsekuensi yang dirasakan (perceived severity), manfaat positif potensial dari tindakan (perceived benefits), hambatan yang dirasakan untuk bertindak, faktor yang mempercepat suatu pemilihan tindakan (cues to action), dan keyakinan akan keberhasilan (self-efficacy). ${ }^{8}$ Berdasarkan health belief model, individu akan mengubah perilakunya ketika mereka memahami bahwa penyakitnya serius. Jika tidak, mereka mungkin tidak akan beralih ke perilaku yang lebih baik. ${ }^{9}$

Health belief model (HBM) diterapkan dengan berfokus pada sikap, persepsi, dan praktik individu. Model ini menyarankan bahwa seseorang akan mengambil tindakan yang berhubungan dengan kesehatan, termasuk memilih pengobatan alternatif, jika orang tersebut merasa bahwa efek samping dapat dihindari, memiliki harapan kesembuhan yang lebih baik, atau kemungkinan untuk penyakitnya bertambah berat dapat berkurang. ${ }^{10}$ Health belief model berlaku baik untuk alasan penderita fraktur memilih meng-gunakan pengobatan alternatif. Ketika individu mendapatkan bahwa mereka rentan terhadap penyakit tertentu, individu tersebut akan berusaha menggunakan pengobatan alternatif sebagai metode pencegahan sebelum penyakit menjadi lebih berat. Ketika seseorang menganggap diagnosisnya serius, maka ia dapat mempertimbangkan untuk menggunakan pengobatan alternatif sehubungan dengan perawatan yang diterima dari praktisi konvensional, sebagai cara untuk memanfaatkan semua perawatan yang dapat digunakan. Namun, jika seseorang tidak percaya pada pengobatan alternatif, maka ia mungkin melihat hal ini sebagai hambatan dan memilih untuk menggunakan pengobatan konvensional saja. ${ }^{11}$

Penelitian ini juga menginvestigasi pengambilan tindakan oleh subjek penelitian, ketika mendapati kasus fraktur. Hasil penelitian ini menunjukkan bahwa mayoritas subjek penelitian ini memilih untuk pergi ke tukang pijat sebagai tindakan awal ketika menemui kasus fraktur. Hal ini juga didukung oleh jawaban subjek penelitian yang menyatakan bahwa tempat yang paling direkomendasikan untuk mengobati fraktur ialah tukang pijat. Alasan lebih dipilihnya tukang pijat sebagai tempat pengobatan pertama fraktur ialah karena lebih dipercaya oleh mayoritas subjek penelitian ini. Sementara itu, rumah sakit berada di urutan kedua dalam hal tempat yang direkomendasikan untuk mengobati fraktur. Bahkan dalam hal pemilihan tindakan awal, rumah sakit menempati posisi ketiga, di bawah pilihan untuk mengonsumsi obat warung. Berdasarkan uraian tersebut, terlihat bahwa mayoritas subjek penelitian ini lebih percaya terhadap tukang pijat daripada rumah sakit untuk mengatasi kasus fraktur. Uniknya, rumah sakit tetap menjadi pilihan untuk menangani fraktur bila tindakan di tukang pijat atau konsumsi obat warung tidak berhasil. Hal ini dibuktikan oleh penelitian 
Wijaya $^{12}$ yaitu 77 responden setuju bahwa pengobatan alternatif dapat menyembuhkan secara total dan 77 responden tertarik memilih pengobatan alternatif fraktur karena keampuhannya, artinya bahwa faktor keberhasilan dan manfaat sangat memengaruhi persepsi terhadap pengobatan alternatif.

Penelitian ini juga mendapatkan hasil yang miris, yaitu sebanyak $4,3 \%$ subjek penelitian ini lebih memilih untuk membiarkan kasus fraktur. Meskipun jumlahnya sedikit, tetapi hasil ini menandakan bahwa masih ada sebagian masyarakat yang mengabaikan kasus fraktur. Namun, penelitian ini tidak dapat mengidentifikasi alasan pasti dari pemilihan tindakan tersebut. Hal lain yang juga ditemukan ialah alasan tradisi yang cukup besar dalam pemilihan tindakan untuk penanganan kasus fraktur. Didapatkan sebanyak $18,7 \%$ subjek penelitian menyebutkan bahwa tradisi turun temurun merupakan dasar dalam memilih tindakan penanganan kasus fraktur. Menurut studi kasus Mumuh et al, ${ }^{13}$ terdapat pengaruh faktor budaya bagi masyarakat Indonesia khususnya masyarakat di Sunda karena terapi tradisional penyakit tulang bukan fenomena baru tetapi sudah membudaya dari generasi ke generasi. ${ }^{13}$

Hasil penelitian ini sejalan dengan penelitian yang dilakukan oleh Fardani ${ }^{4}$ di Bandung, Jawa Barat. Penelitian dengan desain kualitatif yang melibatkan empat subjek penelitian mendapatkan bahwa ke empat subjek memiliki persamaan dalam memandang pengobatan tradisional pada aspek perceived benefits, perceived barriers, dan cues to action. Berdasarkan health belief model, subjek pertama memaknai pengobatan tradisional sebagai jalan kesembuhan dari Tuhan; subjek kedua memaknai pengobatan tradisional sebagai pengobatan yang bisa dipercaya; subjek ketiga memaknai pengobatan tradisional sebagai pilihan terbaik bagi dirinya; dan subjek keempat memaknai pengobatan tradisional sebagai pengobatan yang memberikan kesembuhan jika meyakininya. Faktor-faktor yang melatarbelakangi pilihan tersebut ialah masalah biaya pengobatan, saran keluarga, pengala- man orang lain, dan pemikiran negatif tentang pengobatan medis. ${ }^{4}$

Penelitian lain yang juga sejalan dengan penelitian ini ialah sebuah penelitian yang dilakukan oleh Sholihah ${ }^{5}$ di Surabaya, Jawa Timur. Penelitian potong lintang ini melibatkan 109 responden dan mendapatkan bahwa faktor yang memengaruhi pengambilan keputusan pada pasien dengan cedera muskuloskeletal yang memilih berobat ke tukang pijat sangkal putung ialah persepsi manfaat, persepsi hambatan, self-efficacy, dan alasan ekonomi, sedangkan faktor usia, pendidikan, dan jenis kelamin tidak berpengaruh. ${ }^{5}$

Penelitian yang dilakukan oleh Kurnia et $\mathrm{al}^{14}$ di Sumedang, Jawa Barat, juga mengemukakan hasil yang mendukung hasil penelitian ini. Penelitian dengan desain potong lintang yang melibatkan 34 responden mendapatkan bahwa terdapat tiga faktor yang paling memengaruhi seseorang untuk memilih berobat ke pengobatan tradisional, yaitu faktor motivasi untuk menyembuhkan sakitnya $(64,7 \%)$, kepercayaan akan mendapatkan manfaat sekaligus rendahnya hambatan $(61,76 \%)$, serta pelayanan kesehatan dan kepercayaan terhadap penyedia layanan $(71,88 \%) .{ }^{14}$ Hasil serupa juga ditunjukkan pada penelitian yang dilakukan oleh Rachman et al $^{15}$ di Kalimantan Selatan. Penelitian kualitatif dengan desain fenomenologi tersebut mendapatkan bahwa mayoritas masyarakat Kalimantan Selatan memilih pemanfaatan pelayanan kesehatan tradisional, termasuk pengobatan dengan keterampilan tanpa alat, yaitu pijat urut (lebih dikenal oleh masyarakat sebagai "baurut"). Faktor yang memengaruhi pemilihan tersebut ialah pengaruh budaya, pengalaman orang lain, kecocokan, kepercayaan akan sembuh, dan alasan ekonomi. ${ }^{15}$

Keterbatasan penelitian ini ialah penelitian ini merupakan suatu penelitian deskriptif, sehingga analisis hubungan atau pengaruh tidak dilakukan. Hal ini menyebabkan hubungan antara health belief model dengan kemungkinan pengambilan tindakan ketika mengalami fraktur pada masyarakat tidak diidentifikasi. 


\section{SIMPULAN}

Persepsi masyarakat mengenai kasus fraktur sudah termasuk baik, tetapi masih terdapat ruang untuk peningkatan agar morbiditas dan mortalitas terkait fraktur dapat diturunkan. Masyarakat lebih memilih tukang pijat untuk mendapatkan tindakan awal karena lebih dipercaya, tetapi rumah sakit tetap menjadi tujuan bila tindakan awal tidak berhasil. Alasan tradisi masih menjadi salah satu dasar dalam pemilihan tindakan untuk penanganan kasus fraktur.

\section{Konflik Kepentingan}

Penulis menyatakan tidak terdapat konflik kepentingan dalam studi ini.

\section{DAFTAR PUSTAKA}

1. Sumirat WL, Subagya S, Rochani S. Perilaku masyarakat pada pengobatan alternatif. Pendidik Sosiol. 2017;1-15. Available From:https://Media.Neliti.Com/ Media/ Publications/164679-ID-PerilakuMasyarakat-Pada-Pengobatan-Trad.Pdf

2. Green EC, Murphy E. Health belief model. In: Cockerham WC, Dingwall R, Quah SR, editors. The Wiley Blackwell Encyclopedia of Health, Illness, Behavior, and Society. Chicester: John Wiley \& Sons, 2014.

3. Abraham C, Sheeran P. The health belief model. In: Ayers S, Baum A, McManus C, Newman S, Wallston K, Weinman J, et al, editors. Cambridge Handbook of Psychology, Health and Medicine (2nd ed). Cambridge University Press, 2014.

4. Fardani NW. Gambaran health belief model pada individu yang pernah menjalani pengobatan tradisional bengkel tulang [Tesis]. Bandung: UIN Sunan Gunung Djati; 2018.

5. Sholihah S. Analisis faktor yang mempengaruhi pengambilan keputusan pada pasien cedera muskuloskeletal yang memilih berobat ke sangkal putung berdasarkan pendekatan teori health belief model [Tesis]. Surabaya: Universitas Airlangga; 2019.

6. Setiawan Y. Kemdikbud upayakan wajib belajar 12 tahun melalui PIP |Direktorat
SMK [Internet]. 2016 [Cited 2020 Dec 8]. Available from: http://Smk.Kemdik bud.Go.Id/Konten/1906/KemdikbudUpayakan-Wajib-Belajar-12-TahunMelalui-Pip

7. Sholihah M. Gambaran peluang perubahan perilaku perokok dengan health belief model pada pasien hipertensi di Puskesmas Ciputat Tangerang Selatan. 2014. Available from: repository uinjkt.ac.id.

8. Herold ES. The health belief model. J Sch Health. 1983;53(1):19-21. Available from: https://Doi.Org/10.1111/J.17461561.1983.Tb04047.X

9. Jeihooni AK, Hidarnia A, Kaveh MH, Hajizadeh E, Askari A. The effect of an educational program based on health belief model on preventing osteoporosis in women. Int J Prev Med. 2015;2015.

10. Carpenter CJ. A meta-analysis of the effectiveness of health belief model variables in predicting behavior. Health Commun. 2010;25(8):661-9.

11. Albashtawy M, Gharaibeh $\mathrm{H}$, Alhalaiqa F, Batiha AM, Freij M, Saifan A, Et Al. The health belief model's impacts on the use of complementary and alternative medicine by parents or guardians of children with cancer. Iran $\mathbf{J}$ Public Health. 2016;45(5):708-9.

12. Wijaya M. Persepsi pasien fraktur tentang pengobatan alternatif di Cimande Ciputat Tangerang. 2016. Available From: http://Repository.Uinjkt.Ac.Id/Dspace/ Handle/123456789/37368

13. Zakaria MM, Mahzuni D, Septiani A. Pengobatan alternatif penyakit tulang studi kasus kearifan lokal para terapis penyakit tulang di wilayah Jawa Barat. Patanjala J Penelit Sej Dan Budaya. 2019;11(3):431.

14. Kurnia SH, Kosasih CE, Prawesti PA. Faktorfaktor yang melatarbelakangi pasien patah tulang berobat ke pengobatan tradisional ahli tulang di Sumedang. Students E-Journal. 2012;1(1):1-14.

15. Rachman A, Ilmi B, Mulyani Y. Studi fenomenologi pengalaman pasien dalam penanganan patah tulang dengan ba' urut. Jurnal Keperawatan Suaka Insan|. 2020;5(1):164-74. 